\title{
RESEARCH
}

Open Access

\section{Potential of some endophytic bacteria in biological control of root-knot nematode Meloidogyne incognita}

\author{
Shalaleh Moslehi ${ }^{1 *} \mathbb{D}$, Salar Pourmehr ${ }^{1}$, Akbar Shirzad $^{1}$ and Reza Khakvar ${ }^{2}$
}

\begin{abstract}
Background: Root-knot nematodes (Meloidogyne spp.) are among the most important plant pathogens. Biological control is one of the safety and effective methods for control of these nematodes. The aim of the present study was the isolation and identification of endophytic bacteria from tomato fields in some areas of Iran in order to evaluate their biocontrol potential against root-knot nematode. In the present study, the population of Meloidogyne was collected from infected cucumber roots of a greenhouse, and the bacteria were isolated from tomato samples collected from the fields in West-Azarbaijan province of Iran. The effects of the bacterial isolates on hatching and mortality of nematode second-stage juveniles were evaluated, and the effects of six selected isolates on infection of a susceptible cultivar of tomato with nematode were evaluated under greenhouse conditions.

Results: The root-knot nematode was identified as Meloidogyne incognita. Results showed that the all isolates exhibited considerable inhibitory effects on nematode hatching. The bacterial isolates also caused the mortality of juveniles. Six bacterial isolates with notable biocontrol potential were selected, and supplementary experiments and molecular identification of selected bacterial isolates were performed. Isolates 1, 2, 5, 7, 10, and 11 were identified as follows: Bacillus wiedmannii (MW405861), Pseudoxantomonas mexicana (MW405860), Pseudomonas thivervalensis (MW405862), Serratia liquefaciens (MW405864), Pseudomonas chlororaphis (MW405863), and P. fluorescens (MW405825), respectively. Based on the results of the greenhouse experiment, the selected isolates exhibited good results in terms of reduction of galls and egg masses of nematode. However, B. wiedmannii and S. liquefaciens had the best results in reduction of all investigated factors compared to other isolates. P. mexicana, P. chlororaphis, and $P$. fluorescens resulted moderate effects. $P$. thivervalensis was less effective than the others and in some cases had no effect on nematode reduction.
\end{abstract}

Conclusions: The results showed that endophytic bacteria are good candidates for management of root-knot nematodes. The use of such agents instead of chemicals will be very valuable to the control of nematodes.

Keywords: Meloidogyne incognita, Endophytic bacteria, Antagonist, Bacillus, Biocontrol, Tomato

\footnotetext{
* Correspondence: sh.moslehi@yahoo.com

'Plant Protection Department, Faculty of Agriculture, Azarbaijan Shahid

Madani University, Tabriz, Iran

Full list of author information is available at the end of the article
}

\section{Springer Open}

(c) The Author(s). 2021 Open Access This article is licensed under a Creative Commons Attribution 4.0 International License, which permits use, sharing, adaptation, distribution and reproduction in any medium or format, as long as you give appropriate credit to the original author(s) and the source, provide a link to the Creative Commons licence, and indicate if changes were made. The images or other third party material in this article are included in the article's Creative Commons licence, unless indicated otherwise in a credit line to the material. If material is not included in the article's Creative Commons licence and your intended use is not permitted by statutory regulation or exceeds the permitted use, you will need to obtain permission directly from the copyright holder. To view a copy of this licence, visit http://creativecommons.org/licenses/by/4.0/. 


\section{Background}

Root-knot nematodes (Meloidogyne spp.) are considered as the most important damaging nematodes in terms of economic damage, especially in developing countries (Perry et al. 2009). These nematodes are obligatory endo-parasites inhabiting the roots and cause structural, physiological, and biochemical changes in the host plants. Among the well-known species of the genus, four species, $M$. incognita, $M$. javanica, $M$. arenaria, and $M$. hapla are the most common and important species (Taylor and Sasser 1978).

The use of resistant or non-host crop plants, fallowing or flooding, application of nematicides, and more recently the use of microbial antagonists and biocontrol agents are the principal methods for management of root-knot nematodes (RKN). Antagonistic plants, fungi, and bacteria are among the most important agents for management of the nematodes. One of the most studied and promising examples of natural control of plantparasitic nematodes (PPN) is the bacterial biocontrol agent. These bacteria occur in soil and cause a high degree of nematode suppression (Vagelas 2015). These pathogens save the environment from polluted air, soil, animals, and plants as well as protecting human beings from numerous diseases (Eissa and Abd-Elgawad 2015). Advances in the last decades have produced a number of nematophagous bacteria-based products, containing live microorganisms or their metabolites that are already marketed. Some of the well-accepted commercial products contain the bacteria Bacillus firmus and Pasteuria penetrans (Lamovšek et al. 2013).

Rhizobacteria refer to those bacteria that are capable of colonizing the rhizosphere aggressively (Schroth and Hancock 1982). Aerobic endosporeforming bacteria, mostly Bacillus spp. and Pseudomonas spp., are among the prevailing populations, which inhabit the rhizosphere and are able to antagonize PPN (Tian et al. 2007). B. subtilis is very frequently found in soil and has therefore received numerous studies. Serratia marsescens, Pseudomonas flourescens, Corynebacterium paurometabolu, Rhizobium etli, Bacillus mycoides, P. putida, and Stenotrophomona sp. are some examples of rhizobacters that suppress nematode populations. B. thuringiensis is a bacterium that forms parasporal crystals during the stationary phase (Schnepf et al. 1998). Abdelmoneim and Massoud (2009) found that the spherical crystal toxin gave the highest reduction in nematode population because they can easily pass through the nematode stoma. These proteins are pore-forming toxins that are lethal against insects and some phytonematodes (Abd-Elgawad 1995).

Endophytic bacteria are always found internally in roots, and to a less extent in stem tissue, where such microorganisms can persist in most plant species. This group may be encountered in fruits and vegetables, and are present in both stems and roots, but do not damage to the inhabited host. These bacteria can be easily cultured, have the privilege of application as seed treatment, can reduce initial damage to plant roots, get rid of competition with other microbes and can also modify host's response to PPN attack, can enhance growth of the colonized plant, but do not cause phytotoxic symptoms, and can make use of root exudates for multiplication (Siddiqui and Shaukat 2003). Many studies have been conducted on evaluation of biocontrol effect of endophytic bacteria on PPN. Microbacterium esteraomaticum, Burkholderia sp., some species of Serratia, Pseudomonas, and Yarsinia sp. are among the endophytic bacteria.

The aim of the present study was the isolation and identification of endophytic bacteria from tomato fields in some area of Iran in order to evaluate biocontrol potential on RKN. Evaluation of effects of these bacterial isolates on reproductively of $M$. incognita and infection of tomato with nematode was the main purpose of this study in order to identify and present of native biocontrol agents against RKN.

\section{Main text \\ Methods \\ Isolation and identification of nematode}

Infected root samples were collected from a tomato greenhouse around the Urmia, West Azarbaijan province of Iran. The infected roots were isolated and propagated from a single egg mass of nematode on susceptible tomato cultivar, Super Strain B in greenhouse conditions with $27 \pm 2{ }^{\circ} \mathrm{C}$ and $16: 8$ photoperiods.

Identification of nematode species was carried out using of perineal patterns of the females and subsequently confirmed with molecular identification using species-specific primers. The extraction of nematode genomic DNA was performed using modified method of Holterman et al. (2006). Polymerase chain reaction (PCR) was carried out in $10 \mu \mathrm{l}$ solutions which consists of $4 \mu \mathrm{l}$ of Ampliqon ${ }^{\circ}$ 2X Master mix, $0.5 \mu \mathrm{M}$ of each specific primers of $M$. incognita (Zijlstra et al. 2000), $100 \mathrm{ng}$ of template DNA, and $\mathrm{ddH}_{2} \mathrm{O}$. The reactions were carried out using Biorad $^{\circ} \mathrm{My}$ Cycler ${ }^{\mathrm{TM}}$ as the following profile: one cycle of $4 \mathrm{~min}$ at $94^{\circ} \mathrm{C}$; 35 cycles including $94^{\circ} \mathrm{C}, 30 \mathrm{~s} ; 55^{\circ} \mathrm{C}, 40 \mathrm{~s}$; and $72{ }^{\circ} \mathrm{C}$, $50 \mathrm{~s}$; and a cycle of $7 \mathrm{~min}$ at $72^{\circ} \mathrm{C}$. The PCR products were loaded into agarose gel $1 \%$ that was stained by ethidium bromide. The results were observed in gel documentation (BioDocAnalyze, Biometra ${ }^{\circ}$, Germany) under long UV light. 


\section{Preparation, isolation, and identification of endophytic bacteria}

In order to isolate of endophytic bacteria, samplings were performed from the multiple tomato farm soils. In laboratory, endophytic bacteria were isolated based on the Coombs and Franco (2003) method, using various parts of roots and shoots of the plants. Well sterilized and excised plant tissues were cultured in nutrient agar (NA) medium Liofilchem ${ }^{\bullet}$, Italy, and incubated at $28^{\circ} \mathrm{C}$ in incubator, Nabziran company, Iran. The resulted bacterial colonies were cultured and purified using single colonies. In this survey, 51 bacterial isolates were purified from different parts of plants of all samples. Twenty-two isolates were selected for biochemical identifications based on morphology of the colonies. In order to identify the bacterial isolates, some biochemical assays were performed (Hugh and Leifson 1953; Suslow et al., 1982 and Schaad et al. 2001). Gram staining, catalase, oxidase, lecithinase, and OF tests were among the conducted tests. The production of Levan, Indole, $\mathrm{H}_{2} \mathrm{~S}$, and the hydrolyses of casein, gelatin, starch, methyl red, ability of growth in 41 and $4{ }^{\circ} \mathrm{C}$, tolerance in 5$7 \% \mathrm{NaCl}$, and $\mathrm{HR}$ on tobacco were the other tests for identification of the isolates.

Six selected bacterial isolates $(1,2,5,7,10$, and 11) were molecularly identified, using $16 \mathrm{~S}$ rDNA sequencing. Extraction of bacterial genomic DNA was performed using the modified method of Omar et al. (2014). PCR tests were carried out in $50 \mu$ l solutions which consisted of $20 \mu \mathrm{l}$ of Ampliqon ${ }^{\odot} 2 \mathrm{X}$ Master mix, $2 \mu \mathrm{M}$ of each primer of $16 \mathrm{~S}$ rDNA region, 100 ng of template DNA, and $\mathrm{ddH}_{2} \mathrm{O}$. The reactions were done using Biorad ${ }^{\circledR}$ My Cycler TM Thermal Cycler as the following profile: one cycle of $8 \mathrm{~min}$ at $94{ }^{\circ} \mathrm{C} ; 40$ cycles of $94{ }^{\circ} \mathrm{C}, 25 \mathrm{~s} ; 55^{\circ} \mathrm{C}, 45 \mathrm{~s}$; and $72{ }^{\circ} \mathrm{C}, 30 \mathrm{~s}$; and a cycle of $7 \mathrm{~min}$ (Baker et al. 2003 and Awad and Germoush 2017). The PCR products were loaded into agarose gel $1 \%$ that stained by ethidium bromide. The results were observed in gel documentation (BioDocAnalyze, Biometra ${ }^{\circledR}$, Germany) under long UV light. The PCR products were sent for sequencing to Takapouzist Company, Tehran, Iran. The sequencings edited manually and were compared with relevant sequencings in NCBI data base using BLAST website. The sequence alignment was performed by ClustalW algorithm implemented in MEGA software v. 7.0.21. Evaluation of the evolutionary relationship of isolates and phylogenetic tree was generated by the neighborjoining method.

\section{Nematode mortality and egg hatching tests}

The modified method of Siddiqui and Shaukat (2003) was performed for the tests. All of the bacterial isolates were cultured in tryptic soy broth (TSB), Liofilchem ${ }^{\oplus}$, Italy. The cultures were incubated in incubator shaker (ISF1-X Climo-shaker, Kuhner shaker, Switzerland) in condition of $28^{\circ} \mathrm{C}$ and $180 \mathrm{rpm}$. The bacterial media were centrifuged for precipitation and purified with distilled water. Water suspensions of $10^{8} \mathrm{CFU} / \mathrm{ml}$ for all isolates of bacteria were prepared. Preparation of nematode egg suspension was done according to modified method of Hussey and Janssen (2002).

For evaluation of effects of bacterial isolates on hatching of nematode eggs, $1 \mathrm{ml}$ of each suspension was added to wells of 24-well plates with four replicates. Four replicates of distilled water were considered as control. Hundred eggs of nematode were added in each well. The plates incubated at $26 \pm$ $2{ }^{\circ} \mathrm{C}$ and the percentage of hatching were recorded on the 4th day after the experiment. For evaluation of impacts of bacterial isolates on mortality of second-stage juveniles $\left(\mathrm{J}_{2} \mathrm{~s}\right)$, the suspension of juveniles was prepared. The eggs were isolated from the infected roots and transferred into Petri dishes containing sterile water and incubated in $27 \pm 2{ }^{\circ} \mathrm{C}$. Freshly hatched juveniles were collected for 3 days, and the resulted suspension was used for experiment. The isolates of bacteria and plates were prepared just alike the hatching experiment and finally $100 \mathrm{~J}_{2} \mathrm{~s}$ added into the wells. The number of died juveniles was counted 1 to 4 days, and the percentage of mortality was recorded for each day. According to observed data, the 4th day data was selected for analyses. Both experiments were repeated twice, and the average of data was used for statistical analyses.

\section{Greenhouse experiment}

According to results of in vitro experiments, 6 primarily mentioned bacterial isolates $(1,2,5,7,10$, and 11) were selected for greenhouse experiments. Bacterial suspensions were prepared as described above. The suspension of eggs and juveniles of nematode was also prepared for inoculation of plants. The germinated seeds of tomato susceptible cultivar Super Strain B were cultured in trays containing autoclaved soil and perlite with 2:1 ratio. The trays were kept in a greenhouse with $27 \pm 2{ }^{\circ} \mathrm{C}$ and $16: 8 \mathrm{~h}$ photoperiod. Some of six-leaf stages of seedling were treated with bacterial suspensions and soaked in the prepared suspensions for $20 \mathrm{~min}$ and the others placed only in water. The seedlings were transplanted into the experimental pots containing $500 \mathrm{~g}$ of autoclaved soil and perlite with 2:1 ratio. Some of the treatments inoculated with 2000 eggs and $\mathrm{J}_{2} \mathrm{~s}$ of nematode and the rest irrigated with 
water as control. The applied treatments on plants with selected and identified isolates were consisting of the following: $\mathrm{A}_{1}$ (B. wiedmannii), $\mathrm{A}_{2}$ (Pseudoxantomonas mexicana), $\mathrm{A}_{3}$ ( $P$. thivervalensis), $\mathrm{A}_{4}$ ( $S$. liquefaciens), $\mathrm{A}_{5}$ (P. chlororaphis), $\mathrm{A}_{6}$ (P. fluorescens), $\mathrm{B}_{1}$ (B. wiedmannii + nematode), $\mathrm{B}_{2}$ ( $P$. thivervalensis + nematode $), \mathrm{B}_{3}$ (P. thivervalensis + nematode $), \mathrm{B}_{4}$ (S. liquefaciens + nematode), $\mathrm{B}_{5}(P$. chlororaphis + nematode), $\mathrm{B}_{6}$ ( $P$. fluorescens + nematode), $\mathrm{C}_{1}$ (nematode only), and $\mathrm{C}_{2}$ (without bacteria and nematode). The treatments were designed as complete randomized blocks with 4 replicates and kept in greenhouse with $27 \pm 2{ }^{\circ} \mathrm{C}$ and $16: 8 \mathrm{~h}$ photoperiod.

\section{Data collection and analyses}

Forty-five days after inoculation, some infection parameters of nematode on treated plants were recorded as number of galls and egg masses in root systems and per gram of roots and the number of eggs per egg mass. The gall and egg mass indices were assessed according to Taylor and Sasser (1978). The fresh and dry weights of roots and shoots and the height of shoots were also measured. Data analysis and drawing of graphs were performed using $\mathrm{IBM}^{\bullet} \mathrm{SPSS}^{\circ}$ statistics 20 and Microsoft ${ }^{\circ}$ Excel 2013 software. The transformed data were exposed to analysis variance (ANOVA) and significant differences of the genotypes were realized using Duncan's test.

\section{Results}

\section{Identification of nematode species}

According to the morphological data, especially the perineal pattern of the Meloidogyne adult females and some other data, the population was identified as $M$. incognita (Fig. 1a). The resulted PCR fragments confirmed the identification. As expected, the primers amplified a $1200 \mathrm{bp}$ fragment, using M. incognita genomic DNA as template (Fig. 1b).

\section{Identification of bacterial isolates}

A total of 22 different bacterial isolates was isolated from soil samples. The results of biochemical tests of bacterial isolates are listed in Table 1. Except for one isolate, the others were gram-negative. Based on biocontrol assays, isolates with highest biocontrol potential were selected and biochemically identified as Bacillus sp. (isolate 1), Pseudoxanthomonas sp. (isolate 2), Pseudomonas sp. (isolate 5), Pseudomonas sp. (isolate 10), Pseudomonas sp. (isolate 11), and Serratia sp. (isolate 7).

Elecrophoresis of PCR products resulted fragments about $1500 \mathrm{bp}$ for all of tested bacterial isolates (Fig. 2). The results of Phylogenetic tree (Fig. 3) and comparing of sequences with NCBI database showed the most similarity of isolates $1,2,5,7,10$, and 11 with $B$. wiedmannii (MW405861), Pseudoxantomonas Mexicana (MW405860), P. thivervalensis (MW405862), S. liquefaciens (MW405864), P. chlororaphis (MW405863), and $P$. fluorescens (MW405825) respectively.

\section{Nematode egg hatching and mortality}

Statistical analyses showed that there were significant differences among the effects of bacterial isolates in terms of nematode egg hatchings. The mean comparison of data showed that $P$. mexicana significantly caused the most effect on hatching, with $53.87 \%$ reduction compared to control. S. liquefaciens, B. wiedmannii, $P$. thivervalensis, $P$. fluorescens, and $P$. chlororaphis were among the isolates that had significantly good effects on reduction of hatching compared to control and other isolates (Table 2). About the effects of bacteria on nematode $\mathrm{J}_{2} \mathrm{~s}$ mortality, the

\section{A}

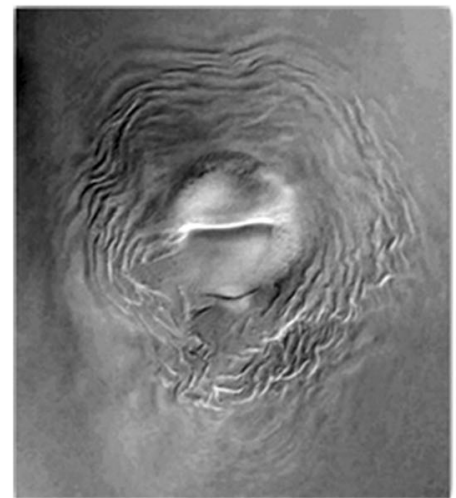

B

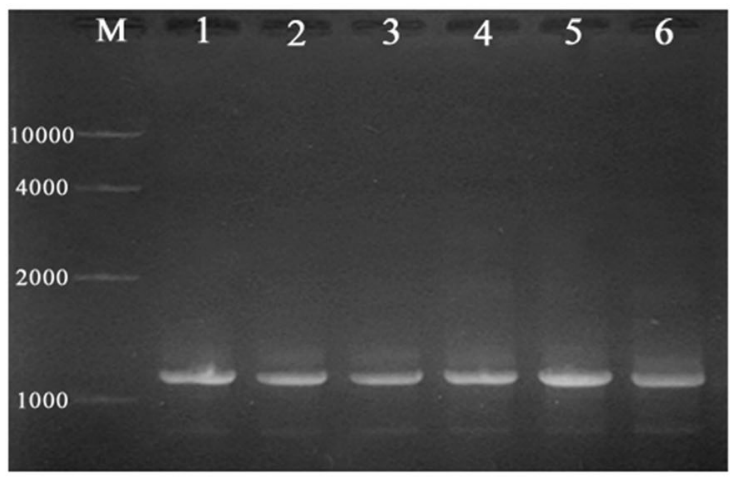

Fig. 1 Perineal pattern of Meloidogyne incognita a. Electrophorogram of PCR products: 1-6: PCR products using nematode genomic DNA as template DNA, in six replications b. M: GeneRuler ${ }^{\text {TM }}$ High Range DNA Ladder, Fermentas $^{\circledR}$ 
Table 1 Results of biochemical tests for bacterial isolates

\begin{tabular}{|c|c|c|c|c|c|c|c|c|c|c|}
\hline Isolates & Gram reaction & $\mathrm{KOH}$ & Catalase & Oxidase & Mobility & $\mathrm{H}_{2} \mathrm{~S}$ & Citrate & Lecithinase & $\mathrm{OF}^{*}$ & Indole \\
\hline 1 & + & + & + & - & + & - & - & + & $\mathrm{F}$ & - \\
\hline 2 & - & - & - & + & - & - & + & - & - & - \\
\hline 3 & - & - & + & - & - & - & -- & - & - & - \\
\hline 4 & - & - & + & + & - & - & + & - & $\mathrm{O}$ & - \\
\hline 5 & - & - & + & + & - & - & + & - & $\mathrm{O}$ & - \\
\hline 6 & - & - & + & + & - & + & + & - & $\mathrm{F}$ & - \\
\hline 7 & - & - & + & + & + & + & + & - & $\mathrm{F}$ & - \\
\hline 8 & - & - & + & + & + & - & + & - & $\mathrm{O}$ & - \\
\hline 9 & - & - & + & + & - & - & + & - & O & - \\
\hline 10 & - & - & + & + & + & - & + & + & $\mathrm{O}$ & - \\
\hline 11 & - & - & + & + & - & - & + & - & O & - \\
\hline 12 & -- & - & + & + & - & + & + & - & $\mathrm{F}$ & + \\
\hline 13 & - & - & + & + & - & - & + & + & - & - \\
\hline 14 & - & - & + & + & -- & + & - & - & -- & + \\
\hline 15 & - & - & + & - & - & - & - & - & F & - \\
\hline 16 & - & -- & + & + & - & + & + & - & F & - \\
\hline 17 & - & - & + & + & + & + & + & - & $\mathrm{F}$ & - \\
\hline 18 & - & - & + & + & - & - & + & - & - & - \\
\hline 19 & - & - & + & - & + & + & + & - & F & - \\
\hline 20 & - & - & + & + & - & - & + & - & - & + \\
\hline 21 & - & - & + & + & - & + & + & - & - & - \\
\hline 22 & - & - & - & + & - & - & + & - & - & - \\
\hline Isolates & $\begin{array}{l}\text { Starch } \\
\text { hydrolysis }\end{array}$ & $\begin{array}{l}\text { Gelatin } \\
\text { hydrolysis }\end{array}$ & $\begin{array}{l}\text { Casein } \\
\text { hydrolysis }\end{array}$ & $\begin{array}{l}\text { Methyl } \\
\text { Red }\end{array}$ & $H R^{* *}$ & $\begin{array}{l}\text { Growth at } \\
41{ }^{\circ} \mathrm{C}\end{array}$ & $\begin{array}{l}\text { Growth at } \\
4^{\circ} \mathrm{C}\end{array}$ & Levan & $\begin{array}{l}\text { Growth in 5\% } \\
\mathrm{NaCl}\end{array}$ & $\begin{array}{l}\text { Growth in } 7 \% \\
\mathrm{NaCl}\end{array}$ \\
\hline 1 & + & + & + & - & - & + & - & - & + & - \\
\hline 2 & - & + & + & - & - & Low & - & + & + & + \\
\hline 3 & - & - & - & - & - & - & - & + & + & - \\
\hline 4 & - & - & - & - & - & - & - & + & + & - \\
\hline 5 & - & - & - & - & - & - & - & + & + & - \\
\hline 6 & - & - & - & + & - & + & - & - & + & - \\
\hline 7 & - & + & + & - & - & - & - & + & + & + \\
\hline 8 & - & - & - & - & - & - & - & + & + & + \\
\hline 9 & - & - & - & - & - & - & - & + & Low & - \\
\hline 10 & - & + & + & - & - & - & - & + & - & - \\
\hline 11 & - & + & - & - & - & - & - & + & - & - \\
\hline 12 & - & + & + & - & - & Low & - & - & + & - \\
\hline 13 & - & + & + & + & - & - & - & - & - & - \\
\hline 14 & + & + & + & + & + & - & - & + & - & - \\
\hline 15 & - & + & + & - & - & + & - & - & - & - \\
\hline 16 & - & + & + & - & - & - & - & + & + & + \\
\hline 17 & - & + & + & - & - & Low & - & - & - & - \\
\hline 18 & - & - & - & - & - & Low & - & + & - & - \\
\hline 19 & - & + & + & - & - & Low & - & + & + & - \\
\hline 20 & - & + & - & - & - & - & - & + & - & - \\
\hline 21 & - & + & - & - & - & - & - & + & - & - \\
\hline 22 & - & - & - & - & + & - & - & + & Low & - \\
\hline
\end{tabular}




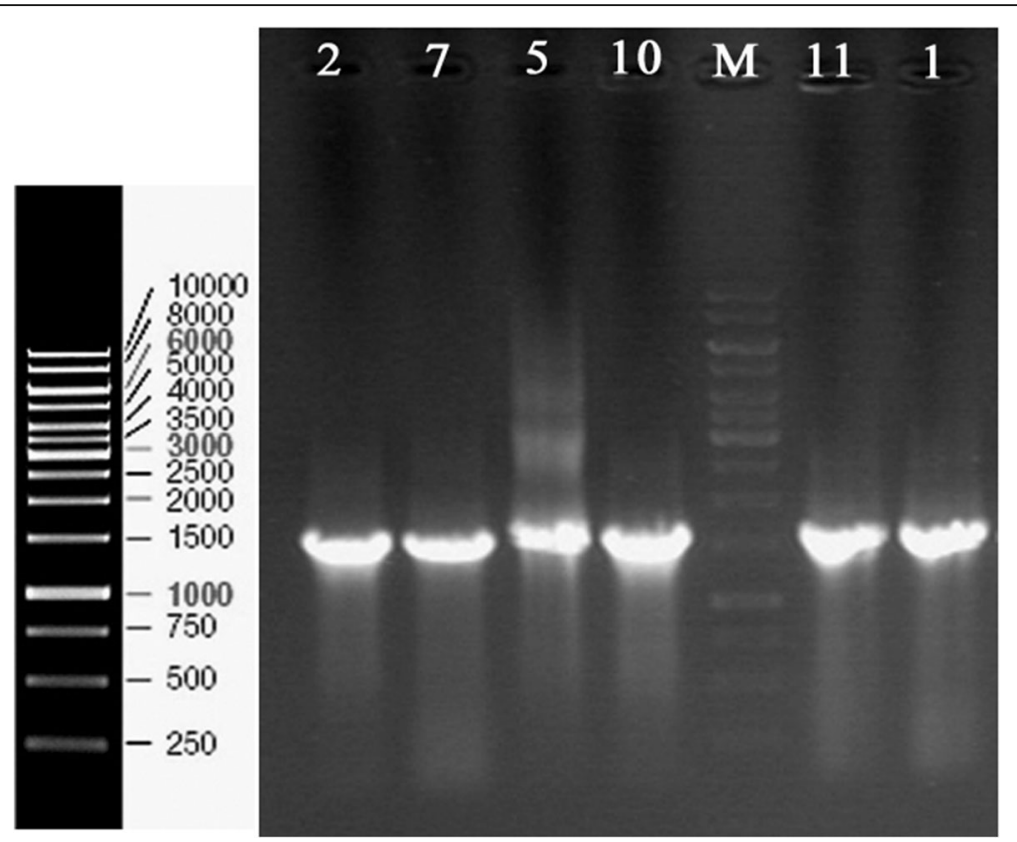

Fig. 2 Electrophoresis pattern of PCR products of 165 rDNA region for bacterial isolates: 1, 2, 5, 7, 10, and 11: number of bacterial isolates. M: GeneRuler $^{\mathrm{TM}} 1$ kb DNA Ladder, Fermentas ${ }^{\circledR}$ )

same 6 mentioned bacteria had more effect on mortality of juveniles. S. liquefaciens with about $70 \%$ mortality than the control had more effect on nematode mortality and the other 5 isolates showed also good mortality impacts on nematode as shown in the Table 2.

\section{Greenhouse experiment}

There were significant differences among treatments in plants growth factors. But no logical and regular correlation was observed among the treatments and they were not sufficient for comparing of treatments with and without bacteria. Nevertheless, the recorded data was mentioned in Table 3.

There were significant differences among treatments in reproductive parameters of nematode in under test plants. The number of root knots in plants inoculated with $B$. wiedmannii + nematode $\left(\mathrm{B}_{1}\right)$ and $S$. liquefaciens + nematode $\left(\mathrm{B}_{4}\right)$ significantly was less (respectively 62 and 65\%) than control plants inoculated with nematode. About the number of knots per gram of roots, nematode-inoculated treatments with $B$. wiedmannii and $S$. liquefaciens had significantly fewer knots (71 and 47\%) than the control. B. wiedmannii, S. liquefaciens, P. fluorescens, and P. chlororaphis significantly reduced the number of egg masses in roots than the control $\left(\mathrm{C}_{1}\right)$.

The number of egg masses per gram of roots was also significantly reduced in plants treated with $B$. wiedmannii, S. liquefaciens, and P. fluorescens compared to control plants.

The plants treated with bacteria had smaller knots in total. All of the treatments significantly had fewer eggs in egg masses compared to control (Fig. 4). Therefore, the bacteria caused smaller and weak egg masses.

Gall indices in plants treated with $B$. wiedmannii and $S$. liquefaciens and egg mass indices in plants treated with $B$. wiedmannii, S. liquefaciens, and P. fluorescens were less than the control (Table 4).

\section{Discussion}

In a study on nematicidal effects of some strains of $P$. polymyxa, B. megaterium, and B. circulans, the results indicated that these bacterial biofertilizers were promising double-purpose microorganisms for mobilizing of soil nutrients and for the biological control of $M$. incognita. Among the applied strains, $P$. polymyxa NFB7, B. megaterium PSB2, and $B$. circulans KSB2 inoculations resulted in the highest reduction in nematode population (El-Hadad et al. 2011).

Park et al. (2014) studied the efficacy of a bacterium for biocontrol of Meloidogyne hapla in carrot and tomato. Among 542 bacterial isolates, the highest nematode mortality was observed in the treatments with $B$. cereus. In pot experiments, the biocontrol efficacy of $B$. cereus was high, showing 


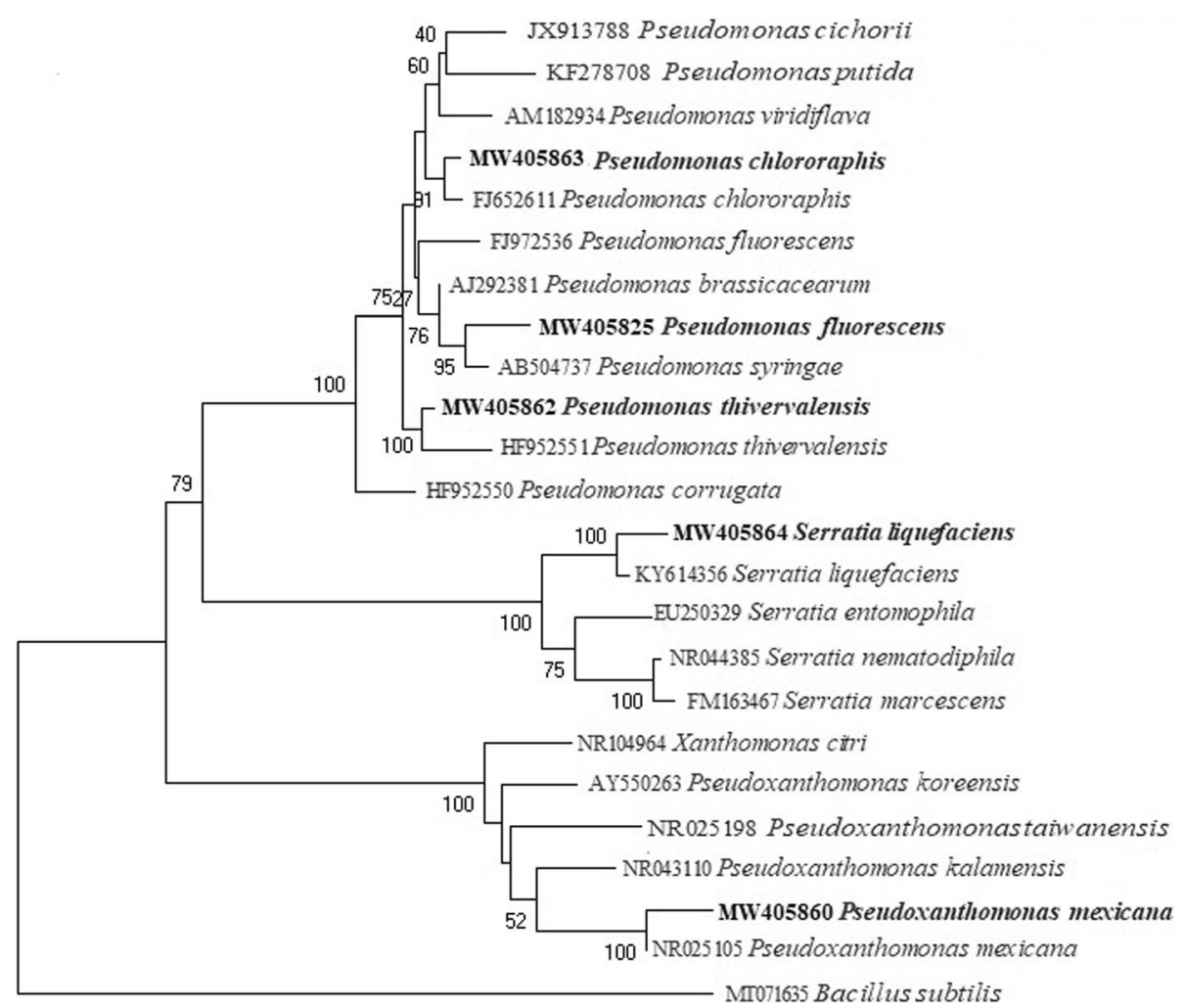

Fig. 3 Phylogenetic tree of five gram negative bacterial isolates, generated by the neighbor-joining method. The bold names are related to isolates: (10). Pseudomonas chlororaphis (MW405863), (11). P. fluorescens (MW405825), (5). P. thivervalensis (MW405862), (7). Serratia liquefaciens (MW405864) and (2), Pseudoxantomonas Mexicana (MW405860)

complete inhibition of root gall or egg mass formation in plants.

$\mathrm{Su}$ et al. (2017) isolated the endophyte bacteria from banana roots, infected by Meloidogyne spp., and were tested against Meloidogyne javanica in the soil. The results showed an important potential of the endophytic strain Streptomyces sp. for the control of plant-parasitic nematodes, especially $M$. javanica.

In another research, Cetintas et al. (2018) determined the effect of some bacterial isolates against $M$. incognita on tomato. Among 15 bacterial strains involved, some species of Mycobacterium, Bacillus, Paenibacillus, Pseudomonas, Tsukamurella, two isolates of Paenibacillus castaneae, and two isolates of Mycobacterium immunogenum were identified as the promising a biocontrol agent for nematode control. $B$. pumilus was the other isolate with good results in reducing root gall number and increasing the plant growth factors.

Vetrivelkalai (2019) were tested some isolates of Pseudomonas sp., Bacillus sp., and Methylbacterium sp. against $M$. incognita in tomato on pot culture condition. The study revealed that the culture filtrates of two Bacillus isolates, Methylobacterium sp., and one isolate of Pseudomonas sp. significantly reduced the number of adult females, egg masses, soil, and root population of $M$. incognita. The lowest root gall index was registered in the isolates of $\mathrm{Ba}$ cillus sp.

Tran et al. (2019) selected active endophytic bacteria for the management of Meloidogyne sp., and all the potential endophytic bacterial strains belong to the genus of Bacillus. In greenhouse tests, Bacillus megaterium significantly reduced nematodes in the soil and pepper plant roots with great inhibition values of $81.86 \%$ and $73.11 \%$, respectively.

As it is known from the results of other researches, the genus Bacillus with different species such as $B$. cereus, $B$. megaterium, and B. circulans are among the most effective bacteria in control of Meloidogyne species. As in the present study, the species B. wiedmannii was one of the most effective species against $M$. incognita. In the case of Serratia, there is some studies about anti-nematode effects of $S$. marcescens against Meloidogyne (Mahfouz et al. 2010; Kassab 
Table 2 Mean comparison of percentage of egg hatching and mortality of $\mathrm{J}_{2} \mathrm{~S}$ in bacterial isolates

\begin{tabular}{|c|c|c|c|}
\hline Isolates & Egg hatching (\%) & Isolates & Mortality (\%) \\
\hline 2 (Pseudoxanthomonas mexicana) & $4.19{ }^{*} \mathrm{a}$ & 7 (Serratia liquefaciens) & $80.82 \mathrm{a}$ \\
\hline 7 (Serratia liquefaciens) & $5.49 \mathrm{~b}$ & 1 (Bacillus wiedmannii) & $74.73 a b$ \\
\hline 1 (Bacillus wiedmannii) & $8.11 \mathrm{~b}$ & 2 (Pseudoxanthomonas mexicana) & $68.29 a b$ \\
\hline 5 (Pseudomonas thivervalensis) & $8.90 \mathrm{bc}$ & 5 Pseudomonas thivervalensis) & $46.06 \mathrm{abc}$ \\
\hline 11 (Pseudomonas fluorescens) & $9.73 b c$ & 11 (Pseudomonas fluorescens) & $58.11 \mathrm{abcd}$ \\
\hline 10 (Pseudomonas chlororaphis) & $9.85 b c$ & 10 (Pseudomonas chlororaphis) & 50.29 bcde \\
\hline 9 & $10.50 \mathrm{bc}$ & 19 & 44.59 cdef \\
\hline 19 & $15.32 \mathrm{c}$ & 9 & 41.62 defg \\
\hline 12 & $16.15 d$ & 22 & 40.12 defg \\
\hline 3 & 17.95 de & 8 & 37.11 defg \\
\hline 8 & 20.07 de & 3 & 37.02 defgh \\
\hline 22 & 20.52 de & 12 & 36.95 defgh \\
\hline 21 & $22.02 \mathrm{de}$ & 6 & 36.70 defgh \\
\hline 4 & 23.26 def & 21 & 36.25 efghi \\
\hline 6 & $24.82 \mathrm{efg}$ & 4 & 34.06 efghi \\
\hline 17 & $39.28 \mathrm{efg}$ & 17 & 30.81 efghi \\
\hline 14 & $43.45 \mathrm{fgh}$ & 14 & $30.20 \mathrm{fghi}$ \\
\hline 13 & $44.03 \mathrm{fgh}$ & 18 & 28.03 fghi \\
\hline 20 & $44.89 \mathrm{fgh}$ & 13 & 24.22 ghij \\
\hline 18 & $46.51 \mathrm{gh}$ & 16 & 22.40 ghij \\
\hline 16 & $49.33 \mathrm{gh}$ & 20 & 20.28 hij \\
\hline 15 & $50.23 \mathrm{~h}$ & 15 & 19.53 ij \\
\hline Control & $58.63 \mathrm{~h}$ & Control & $10.71 \mathrm{j}$ \\
\hline
\end{tabular}

"Means with same letter are not significantly different according to Duncan's test $(P \leq 0.05)$

Table 3 Mean comparison of plant growth factors in greenhouse experiment

\begin{tabular}{lllllll}
\hline Treatments & $\begin{array}{l}\text { Root length } \\
\text { (cm) }\end{array}$ & $\begin{array}{l}\text { Root wet weight } \\
\text { (gr) }\end{array}$ & $\begin{array}{l}\text { Root dry weight } \\
\text { (gr) }\end{array}$ & $\begin{array}{l}\text { Shoot length } \\
\text { (cm) }\end{array}$ & $\begin{array}{l}\text { Shoot wet weight } \\
\text { (gr) }\end{array}$ & $\begin{array}{l}\text { Shoot dry weight } \\
\text { (gr) }\end{array}$ \\
\hline A5** & $35.75 \mathrm{a}^{*}$ & $7.12 \mathrm{bcd}$ & $0.46 \mathrm{~cd}$ & $57.00 \mathrm{a}$ & $20.97 \mathrm{cde}$ & $2.67 \mathrm{abc}$ \\
$\mathrm{A} 6$ & $33.50 \mathrm{ab}$ & $8.37 \mathrm{abcd}$ & $0.52 \mathrm{~cd}$ & $59.25 \mathrm{a}$ & $20.37 \mathrm{cde}$ & $1.95 \mathrm{bc}$ \\
$\mathrm{A} 2$ & $31.75 \mathrm{ab}$ & $12.57 \mathrm{a}$ & $0.53 \mathrm{~cd}$ & $49.25 \mathrm{ab}$ & $35.20 \mathrm{a}$ & $6.35 \mathrm{a}$ \\
$\mathrm{A} 1$ & $31.45 \mathrm{ab}$ & $7.53 \mathrm{bcd}$ & $0.44 \mathrm{~cd}$ & $44.75 \mathrm{~b}$ & $19.00 \mathrm{cde}$ & $2.52 \mathrm{abc}$ \\
A3 & $27.27 \mathrm{abc}$ & $9.56 \mathrm{abc}$ & $0.49 \mathrm{~cd}$ & $46.50 \mathrm{~b}$ & $19.78 \mathrm{cde}$ & $3.35 \mathrm{ab}$ \\
A4 & $27.00 \mathrm{abc}$ & $4.67 \mathrm{~d}$ & $0.33 \mathrm{~d}$ & $43.82 \mathrm{~b}$ & $19.57 \mathrm{cde}$ & $4.12 \mathrm{ab}$ \\
B1 & $26.75 \mathrm{abcd}$ & $10.02 \mathrm{ab}$ & $0.76 \mathrm{~cd}$ & $49.50 \mathrm{ab}$ & $23.35 \mathrm{ab}$ & $3.37 \mathrm{ab}$ \\
C2 & $25.25 \mathrm{abcd}$ & $10.47 \mathrm{ab}$ & $0.77 \mathrm{bcd}$ & $48.92 \mathrm{ab}$ & $20.57 \mathrm{cde}$ & $2.82 \mathrm{abc}$ \\
C1 & $25.00 \mathrm{abcd}$ & $9.15 \mathrm{abcd}$ & $1.57 \mathrm{a}$ & $38.95 \mathrm{~b}$ & $11.57 \mathrm{e}$ & $1.27 \mathrm{c}$ \\
B2 & $24.57 \mathrm{bcd}$ & $9.79 \mathrm{abc}$ & $1.36 \mathrm{ab}$ & $42.75 \mathrm{~b}$ & $24.20 \mathrm{bcd}$ & $2.57 \mathrm{abc}$ \\
B3 & $23.45 \mathrm{~cd}$ & $12.70 \mathrm{a}$ & $1.35 \mathrm{ab}$ & $42.00 \mathrm{~b}$ & $26.17 \mathrm{bc}$ & $3.35 \mathrm{ab}$ \\
B6 & $23.00 \mathrm{~cd}$ & $5.22 \mathrm{~cd}$ & $0.80 \mathrm{bcd}$ & $44.10 \mathrm{~b}$ & $18.12 \mathrm{cde}$ & $1.87 \mathrm{bc}$ \\
B5 & $22.25 \mathrm{~cd}$ & $6.22 \mathrm{bcd}$ & $1.05 \mathrm{abc}$ & $49.25 \mathrm{ab}$ & $15.30 \mathrm{de}$ & $1.26 \mathrm{c}$ \\
B4 & $20.84 \mathrm{~d}$ & $7.82 \mathrm{bcd}$ & $0.95 \mathrm{bcd0}$ & $43.75 \mathrm{~b}$ & $21.25 \mathrm{cde}$ & $3.42 \mathrm{ab}$ \\
\hline
\end{tabular}

"Means with same letter are not significantly different according to Duncan's test $(P \leq 0.05)$

$\mathrm{A}_{1}$ (Bacillus wiedmannii), $\mathrm{A}_{2}$ (Pseudoxantomonas mexicana), $\mathrm{A}_{3}$ (Pseudomonas thivervalensis), $\mathrm{A}_{4}$ (Serratia liquefaciens), $\mathrm{A}_{5}$ (Pseudomonas chlororaphis), $\mathrm{A}_{6}$ (Pseudomonas fluorescens), $B_{1}\left(B\right.$. wiedmannii + nematode), $B_{2}\left(P\right.$. thivervalensis + nematode), $B_{3}\left(P\right.$. thivervalensis + nematode), $B_{4}\left(S\right.$. liquefaciens + nematode), $B_{5}$ (P. chlororaphis + nematode), $B_{6}$ ( $P$. fluorescens + nematode), $C_{1}$ (nematode only), and $C_{2}$ (without bacteria and nematode) 


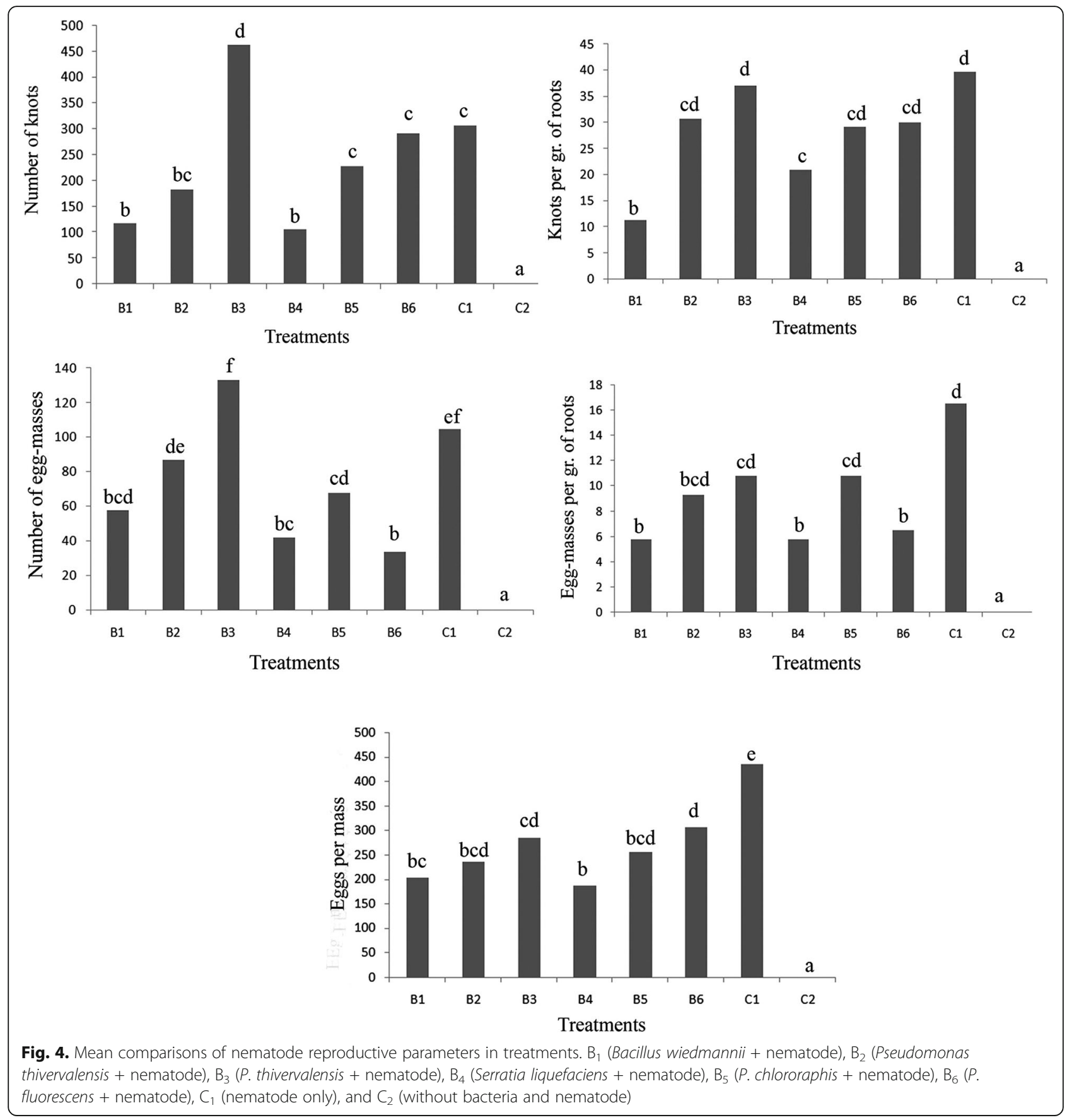

et al. 2017; Hegazy et al. 2019), and in the present study, the species $S$. liquefaciens as an endophytic bacteria was one of the effective species against $M$. incognita.

\section{Conclusions}

The selected isolates exhibited useful results. B. wiedmannii and S. liquefaciens were the best ones in reducing of all investigated factors compared to other isolates. P. mexicana, P. chlororaphis, and P. fluorescens resulted moderate effects and $P$. thivervalensis was the less one. The results showed also that the endophytic bacteria are good candidates for controlling the rootknot nematodes, and it is recommended to conduct additional experiments in laboratories, greenhouses, and fields, because of the use of such a biocontrol agent instead of chemicals will be very valuable for management of nematodes. 
Table 4 Mean comparison of gall and egg mass indices in greenhouse experiment

\begin{tabular}{lll}
\hline Treatments & Gall index (Gl) & Egg mass index (MI) \\
\hline $\mathrm{C}_{2}$ & $0 \mathrm{a}$ & $0 \mathrm{a}$ \\
$\mathrm{B}_{1}$ & $4.5 \mathrm{~b}$ & $3.5 \mathrm{~b}$ \\
$\mathrm{~B}_{2}$ & $5.0 \mathrm{C}$ & $4.25 \mathrm{~cd}$ \\
$\mathrm{~B}_{3}$ & $5.0 \mathrm{C}$ & $4.75 \mathrm{~d}$ \\
$\mathrm{~B}_{4}$ & $4.5 \mathrm{~b}$ & $3.75 \mathrm{bc}$ \\
$\mathrm{B}_{5}$ & $5.0 \mathrm{C}$ & $4.25 \mathrm{~cd}$ \\
$\mathrm{~B}_{6}$ & $5.0 \mathrm{C}$ & $3.5 \mathrm{~b}$ \\
$\mathrm{C}_{1}$ & $5.0 \mathrm{C}$ & $4.5 \mathrm{~d}$ \\
\hline
\end{tabular}

*Means with same letter are not significantly different according to Duncan's test $(P \leq 0.05)$

$\mathrm{B}_{1}$ (B. wiedmannii + nematode), $\mathrm{B}_{2}$ ( $P$. thivervalensis + nematode), $\mathrm{B}_{3}(P$. thivervalensis + nematode), $B_{4}$ (S. liquefaciens + nematode), $B_{5}(P$. chlororaphis + nematode), $B_{6}$ ( $P$. fluorescens + nematode), $C_{1}$ (nematode only), and $C_{2}$ (without bacteria and nematode)

\section{Abbreviations}

$\mathrm{J}_{2}$ s: Second-stage juveniles; PPN: Plant parasitic nematodes; RKN: Root-knot nematode; etc.: Et cetera; NA: Nutrient agar; TSB: Tryptic soy broth; CFU: Colony-forming unit; HR: Hypersensitive response; OF: Oxidative/ fermentative; PCR: Polymerase chain reaction

\section{Acknowledgements}

Not applicable.

\section{Authors' contributions}

ShM (Plant Pathology-Nematology) was the advisor of the thesis and major contributor in writing the manuscript, SP carried out all the experiments (Plant Pathology Student-MSc thesis), and ASh (Plant Pathology-Biological control) and RKh (Plant Pathology-Bacteriology) were the supervisors of the thesis. All authors read and approved the final manuscript.

\section{Funding}

The present study was supported financially by Azarbaijan Shahid Madani University, Tabiz, Iran.

\section{Availability of data and materials}

The datasets used and/or analyzed during the current study are available from the corresponding author on reasonable request.

\section{Declarations}

\section{Ethics approval and consent to participate}

Not applicable.

\section{Consent for publication}

Not applicable.

\section{Competing interests}

The authors declare that they have no competing interests.

\section{Author details}

${ }^{1}$ Plant Protection Department, Faculty of Agriculture, Azarbaijan Shahid Madani University, Tabriz, Iran. ${ }^{2}$ Plant Protection Department, Faculty of Agriculture, University of Tabriz, Tabriz, Iran.

Received: 23 November 2020 Accepted: 23 February 2021 Published online: 12 March 2021

\section{References}

Abd-Elgawad MMM (1995) Evaluation of Bacillus thuringiensis and plant extracts for control of phytonematodes. Egy J Appl Sci 10:1-5
Abdelmoneim T, Massoud S (2009) The effect of endotoxin produced by Bacillus thuringiensis (Bt.) against Meloidogyne incognita. Egy J Nat Toxins 6:83-93

Awad HM, Germoush M (2017) Molecular and morphological identification of Streptomyces sp. NRC-88 nova species as $\beta$-lactamase inhibitor for pharmaceutical application. Asian J Pharm Clin Res 10(10):376-386

Baker GC, Smith JJ, Cowan DA (2003) Review and re-analysis of domain-specific $16 \mathrm{~S}$ primers. J Microbiol Methods 55:541-555

Cetintas R, Kusek M, Fateh A (2018) Effect of some plant growth-promoting rhizobacteria strains on root-knot nematode, Meloidogyne incognita, on tomatoes. Egypt J Biol Pest Co 28:7

Coombs JT, Franco CMM (2003) Isolation and identification of actinobacteria isolated from surface-sterilized wheat roots. Appl Environ Microbiol 69:56035608

Eissa MFM, Abd-Elgawad MMM (2015) Nematofagous bacteria as biocontrol agents of phytonematodes. In: Askari TH, Mertinelli PRP (eds) Biocontrol agents of phytonematodes. CABI, UK, pp 217-243

El-Hadad ME, Mustafa MI, Selim SM, El-Tayeb TS, Mahgoob AEA, Abdel-Aziz NH (2011) The nematicidal effect of some bacterial biofertilizers on Meloidogyne Incognita in sandy soil. Braz J Microbiol 42:102-113

Hegazy MI, Salama ASA, El-Ashry RM, Othman AEI (2019) Serratia marcescens and Pseudomonas aeruginosa are promising candidates as biocontrol agents against root-knot nematodes (Meloidogyne spp.). Middle East J Agric Res 8(3): 828-838

Holterman M, van der Wurff A, van den Elsen S, van Megen $H$, Bongers T, HolovachofO BJ, Helder J (2006) Phylum-wide analysis of SSU rDNA reveals deep phylogenetic relationships among nematodes and accelerated evolution toward crown Clades. Mol Biol Evol 23(9):1792-1800

Hugh R, Leifson E (1953) The taxonomic significance of fermentative versus oxidative metabolism of carbohydrates by various gram negative bacteria. J Bacteriol 66:24-26

Hussey RS, Janssen GJW (2002) Root-knot nematodes: Meloidogyne species. In: Starr JL, Cook R, Bridge J (eds) Plant resistance to parasitic nematodes. CABI, Wallingford, pp 43-70

Kassab SA, Eissa MFM, Badr UM, Ismail AE, Abdel Razik AB, Gaziea MS (2017) Nematicidal effect of a wild type of Serratia Marcescens and its mutants against Meloidogyne incognita juveniles. Egypt J Agronematol 16(2):95-114

Lamovšek J, Urek G, Trdan S (2013) Biological control of root-knot nematodes (Meloidogyne spp.): microbes against the pests. Acta Agric Slov 101:263-275

Mahfouz M, Abd-Elgawad M, Kabeil SSA (2010) Management of the root-knot nematode, Meloidogyne incognita on Tomato in Egypt. J Am Sci 6(8):256-262

Omar BA, Atif HA, Mogahid ME (2014) Comparison of three DNA extraction methods for polymerase chain reaction (PCR) analysis of bacterial genomic DNA. Microbiol Res 8(6):598-602

Park J, Seo Y, Kim YH (2014) Biological control of Meloidogyne hapla using an antagonistic bacterium. Plant Pathol J 30(3):288-295

Perry RN, Moens M, Starr 」L (2009) Root-knot nematodes. CABI, Wallingford

Schaad NW, Jones JB, Chun W (2001) Laboratory guide for identification of plant pathogenic bacteria, 3rd edn. APS Press, USA

Schnepf E, Crickmore N, Van Rie J, Lereclus D, Baum J, Feitelson J, Zeigler DR, Dean DH (1998) Bacillus thuringiensis and its pesticidal crystal proteins. Microbiol Mol Biol Rev 62:775-806

Schroth MN, Hancock JG (1982) Disease suppressive soil and root colonizing bacteria. Science 216:1376-1381

Siddiqui IA, Shaukat SS (2003) Endophytic bacteria: prospects and opportunities for the biological control of plant-parasitic nematodes. Nematol Mediterr 31: 111-120

Su L, Shen Z, Ruan Y, Tao C, Chao Y, Li R, Shen Q (2017) Isolation of antagonistic endophytes from banana roots against Meloidogyne javanica and their effects on soil nematode community. Front Microbiol 8:1-11

Suslow TV, Schroth MN, Isaka M (1982) Application of a rapid method for gram differentiation of plant pathogenic and saprophytic bacteria without staining. Phytopathol 72:917-918

Taylor AL, Sasser JN (1978) Biology, identification and control of root-knot nematodes (Meloidogyne species). North Carolina State University Graphics. Raleigh NC, USA

Tian B, Yang J, Zhang KG (2007) Bacteria used in the biological control of plant parasitic nematodes: populations, mechanisms of action and future prospects. FEMS Microbiol Ecol 61:197-213

Tran TPH, Wang SL, Nguyen VB, Tran DM, Nguyen DS, Nguyen AD (2019) Study of novel endophytic bacteria for biocontrol of black pepper 
root-knot nematodes in the central highlands of Vietnam. Agron. 9(714):2-12

Vagelas IK (2015). Novel bacteria species in nematode biocontrol. In: Askari TH, Mertinelli PRP (eds.) Biocontrol agents of phytonematodes. CABI, Wallingford

Vetrivelkalai P (2019) Evaluation of endophytic bacterial isolates against root knot nematode, Meloidogyne incognita in tomato under glasshouse condition. Int J Curr Microbiol App Sci 8(1):2584-2589

Zijlstra C, Donkers-Venne DTHM, Fargette M (2000) Identification of Meloidogyne incognita, M. javanica and $M$. arenaria using sequence characterised amplified region (SCAR) based PCR assays. Nematol 2:847-853

\section{Publisher's Note}

Springer Nature remains neutral with regard to jurisdictional claims in published maps and institutional affiliations.

\section{Submit your manuscript to a SpringerOpen ${ }^{\circ}$ journal and benefit from:}

- Convenient online submission

- Rigorous peer review

- Open access: articles freely available online

- High visibility within the field

- Retaining the copyright to your article

Submit your next manuscript at $\boldsymbol{\nabla}$ springeropen.com 